\title{
BESAR KURVA THORAKAL DAN LUMBAL MODIFIER SEBAGAI FAKTOR PREDIKSI TERHADAP KOREKSI SPONTAN KURVA LUMBAL PASKA OPERASI PADA ADOLESCENT IDIOPATHIC SCOLIOSIS LENKE I
}

\section{MAIN THORACIC CURVE MAGNITUDE AND LUMBAR MODIFIER AS PREDICTION FACTORS FOR LUMBAR CURVE SPONTANEOUS CORRECTION AFTER OPERATION IN ADOLESCENT IDIOPATHIC SCOLIOSIS LENKE I}

\author{
Anggita Tri Yurisworo ${ }^{1}$, Bagas Widhiarso ${ }^{1}$, Andhi Prijosedjati ${ }^{2}$, Pamudji Utomo ${ }^{2}$ \\ ${ }^{1}$ Resident of Orthopaedic and Traumatology Faculty of Medicine Universitas Sebelas Maret \\ ${ }^{2}$ Departement of Orthopaedic and Traumatology Faculty of Medicine Universitas Sebelas Maret - \\ Rumah Sakit Ortopedi Pusat Dr.Soeharso Surakarta \\ Korespondensi: dr. Anggita Tri Yurisworo. Email: anggiortho@gmail.com
}

\begin{abstract}
ABSTRAK
Pola kurva thorakal utama pada Adolescent idiopathic scoliosis Lenke I adalah kurva utama sedangkan kurva torakal proksimal dan kurva torakolumbal/lumbar sebagai kurva minor non struktural. Instrumentasi dan fusi dari daerah toraks media direkomendasikan dalam tatalaksana penyakit ini. Kurva lumbal mengalami koreksi spontan untuk menyeimbangkan kurva toraks setelah dilakukan fusi toraks yang selektif. Kurva lumbar dapat dikategorikan ke dalam lumbar modifier A, B, dan C. Tatalaksana operatif yang spesifik tergantung dari kategori tersebut. Penelitian ini adalah penelitian analisis observasional pada 35 pasien dengan Adolescent idiopathic Scoliosis Lenke I yang sudah menjalani koreksi dan operasi instrumentasi posterior. Evaluasi dilakukan dengan foto sinar-X sebelum dan sesudah operasi untuk menentukan lumbar modifier, besarnya lengkung kurva toraks media (main thoracic) dan koreksi lumbar yang terjadi spontan. Hubungan antara besarnya koreksi lengkung thoraks media (main thoracic) dengan koreksi kurva lumbar spontan memiliki nilai signifikansi $p=0,000(<0,05)$. Besarnya koreksi lengkung toraks media (main thoracic) memiliki koefisien regresi yang lebih besar daripada lumbar modifier untuk koreksi kurva lumbar spontan (0,764 dan 0,092). Penelitian ini menyimpulkan bahwa besarnya koreksi lengkung thoraks media (main thoracic) memiliki hasil yang lebih signifikan pada koreksi kurva lumbar spontan dan ini adalah faktor yang paling dominan untuk mempengaruhi koreksi kurva lumbar spontan dibandingkan dengan lumbar modifier.
\end{abstract}

Kata kunci: Adolescent Idiopathic Scoliosis, Lumbar Modifier, Main Thoracic

\begin{abstract}
Main thoracic curve pattern is the major curve in adolescent idiopathic scoliosis Lenke I., whereas the proximal thoracic and thoracolumbar/lumbar curve are being non structural minor curves. Thus, instrumentation and fusion of the main thoracic region are recommended. Lumbar curve will be corrected spontaneously to balance the thoracic curve after selective thoracic fusion. Lumbar curve can be categorized into lumbar modifier $A, B$, and $C$. The choice of specific operative treatment depends on that. This study was an observational analysis in 35 patients with adolescent idiopathic scoliosis Lenke I after correction and posterior instrumentation surgery. Evaluation was carried out using X-rays before and after surgery to determine lumbar modifier, magnitude of the main thoracic curve and assessment of spontaneous lumbar curve correction. Correlation between magnitude of main thoracic curve correction to the spontaneous lumbar curve correction has a significance value $p=0.000(<0.05)$. Magnitude of main thoracic curve correction has a greater regression coefficient than the lumbar modifier for spontaneous lumbar curve correction (0.764 and 0.092). This study conclude that magnitude of main thoracic curve correction has a significant effect on the spontaneous lumbar curve correction and this is the most dominant factor to influence spontaneous lumbar curve correction compared to the lumbar modifier.
\end{abstract}

Keywords: Adolescent Idiopathic Scoliosis, Lumbar Modifier, Main Thoracic

How To Cite: Yurisworo, A., Widiarso, B., Prijosedjati, A., \& Utomo, P. (2019). BESAR KURVA THORAKAL DAN LUMBAL MODIFIER SEBAGAI FAKTOR PREDIKSI TERHADAP KOREKSI SPONTAN KURVA LUMBAL PASKA OPERASI PADA ADOLESCENT IDIOPATHIC SCOLIOSIS LENKE I. Biomedika, 11(2), 74-80. doi:https://doi.org/10.23917/biomedika.v11i2.7629

DOI: https://doi.org/10.23917/biomedika.v11i2.7629 


\section{INTRODUCTION}

Adolescent idiopathic scoliosis (AIS) is a three-dimensional deformity of the spine characterized by scoliosis in the coronal plane, normal physiological loss of curvature in the sagittal plane and vertebral rotation in the horizontal plane (Solomon et al., 2017). Adolescent idiopathic scoliosis occurs between the ages of 10 to 18 years, where the cause is still uncertain. Eighty percent of the overall incidence of scoliosis is idiopathic. The deformity of idiopathic scoliosis is very easy to recognize and the incidence of severe curvature curves (curves more than $40^{\circ}$ ) is 3 per 1000 populations (Lenke, 2007; Solomon et al., 2017).
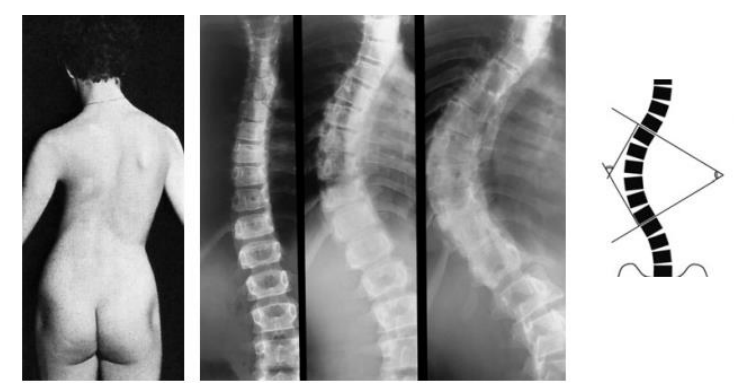

Figure 1. Description of deformity. It is a typical feature of deformed thoracic scoliosis, where a 4-year serial $x$-ray shows an increase in curvature of the curve. Angles are measured according to Cobb's method.

The Scoliosis Research Society, defines scoliosis as follows: The Cobb method is used to measure the curvature of the spine in an upright position with anteroposterior X-ray film and an angle of more than $10^{\circ}$ is considered scoliosis. Surgical action in patients with idiopathic scoliosis is indicated for patients with Cobb's angle of more than $40^{\circ}$ (Labelle et al., 2013).

Table 1. Lenke Classification (Lenke, 2007)

\begin{tabular}{|c|c|c|c|c|c|}
\hline \multirow{2}{*}{$\begin{array}{l}\text { Curve } \\
\text { Type }\end{array}$} & \multirow[t]{2}{*}{ Description } & \multicolumn{3}{|c|}{ Characteristic Curve Patterns* } & \multirow{2}{*}{$\begin{array}{l}\text { Structural Region Of } \\
\text { Each Curve Type }\end{array}$} \\
\hline & & $\begin{array}{l}\text { Proximal } \\
\text { Thoracic }\end{array}$ & Main Thoracic & $\begin{array}{c}\text { Thoracolumbar/ } \\
\text { Lumbar }\end{array}$ & \\
\hline 1 & Main thoracic & Nonstructural & $\begin{array}{l}\text { Structural } \\
\text { (major) }\end{array}$ & Nonstructural & Main thoracic \\
\hline 2 & Double thoracic & Structural & $\begin{array}{l}\text { Structural } \\
\text { (major) }\end{array}$ & Nonstructural & $\begin{array}{l}\text { Proximal thoracic, Main } \\
\text { thoracic }\end{array}$ \\
\hline 3 & Double major & Nonstructural & $\begin{array}{l}\text { Structural } \\
\text { (major) }\end{array}$ & Structural & $\begin{array}{l}\text { Main thoracic, } \\
\text { thoracolumbar/lumbar }\end{array}$ \\
\hline 4 & Triple major & Structural & $\begin{array}{l}\text { Structural } \\
\text { (majort) }\end{array}$ & Structural (major) & $\begin{array}{l}\text { Proximal thoracic, Main } \\
\text { thoracic, } \\
\text { thoracolumbar/lumbar }\end{array}$ \\
\hline 5 & $\begin{array}{l}\text { Thoracolumbar/ } \\
\text { lumbar }\end{array}$ & Nonstructural & Nonstructural & Structural (major) & thoracolumbar/lumbar \\
\hline 6 & $\begin{array}{l}\text { Thoracolumbar/ } \\
\text { lumbar-main thoracic }\end{array}$ & Nonstructural & Structural & Structural (major) & $\begin{array}{l}\text { thoracolumbar/lumbar, } \\
\text { Main thoracic }\end{array}$ \\
\hline
\end{tabular}


still controversial. Although TL / L deviation of CSVL at apex, curved TL / L curves less than $25^{\circ}$ do not have junctional kyphosis and selective thoracic fusion is recommended (Solomon et al., 2017).

Posterior stabilization using a screw pedicle usually involves fusion in the stable vertebra at the T11 level (rare), T12 or L1. Thoracic selective fusion of the type C lumbar modifier is very important to maximize the lumbar movement and can be achieved by evaluation and good surgical techniques, including correction of the thoracic curve to achieve a harmonized balance with the lumbar curve below which fusion is not performed (Herkowitz et al., 2011; Studer et al., 2015).

Fusion of the spine for scoliosis aims to make the spine stiff, so that the spine cannot bend and to correct deformity. Posterior spinal fusion has become part of the management of adolescent idiopathic scoliosis with a Cobb angle of more than $50^{\circ}$. Long-term research has proven that the results of this procedure are satisfactory, and comparative studies show that in severe cases better results with spinal fusion compared to those not fused (Herkowitz et al., 2011; Studer et al., 2015).
Selective thoracic fusion to avoid unnecessary fusion of flexible lumbar curves is explained by King et al. Several articles have shown the capacity of the lumbar curve in relation to the thoracic curve, as a whole. However, in some cases, there may not be enough correction of the lumbar curve and unsatisfactory aesthetic results. Prognostic factors for accommodation of lumbar curvature are not fully established in the current literature (Patel et al., 2008).

Several studies have shown that the lumbar curve can be spontaneously corrected after selective thoracic fusion, in the literature it is explained that spontaneous correction of the lumbar curve occurs in compensation for balancing the thoracic curve after selective thoracic fusion. In several studies it was also explained that excessive correction of the main thoracic curve can result in decompensation of the lumbar curve, but a low degree of correction of the main thoracic curve can still leave the clinical deformity (Jansen et al., 2007; Patel et al., 2008).

\section{METHOD}

This is cross-sectional study ofpostoperative adolescent idiopathic scoliosis patients after correction of deformity and 
posterior instrumentation at the $\mathrm{X}$ Hospital Surakarta in 2015 - 2017. The patient's basic data was taken from Medical Records, then selected on the basis of inclusion and exclusion criteria. The radiological data in the form of $\mathrm{x}$ ray patients who met the inclusion criteria assessed the magnitude of the main thoracic curve and lumbar modifier and postoperative lumbar curve.

\section{RESULT AND DISCUSSION}

In our study conducted on 35 samples of adolescent idiopathic scoliosis Lenke I who had performed a surgical procedure to correct deformity and posterior instrumentation in 2015- 2017 in X Hospital Surakarta, who fulfilled the inclusion and exclusion criteria, found that there were 34 female and 1 male with range of 10 years to 18 years old.

Characteristics of the lumbar modifier type were obtained by lumbar modifier A in 15 patients, lumbar modifiers $\mathrm{B}$ and $\mathrm{C}$ each of 10 patients. For the characteristics of the main thoracic curve, there were 1 patient for the curve more than $90^{\circ}, 12$ patients for the curve between $90^{\circ}-70^{\circ}$ and 22 patients for the curve less than $70^{\circ}$.

Based on the correlation test results processed using SPSS, it was found that the magnitude of the main thoracic curve correction had a significant effect on the spontaneous correction of the postoperative lumbar curve $($ significance value $(\mathrm{Sig})=0,000$ $<0.05)$ and the magnitude of the main thoracic curve correction had a more dominant influence on the lumbar modifier. spontaneous correction of postoperative lumbar curve (large variable correction of thoracic curve $(\mathrm{X} 1)=$ 0.784, Lumbar modifier $(X 2)=0.092)$.

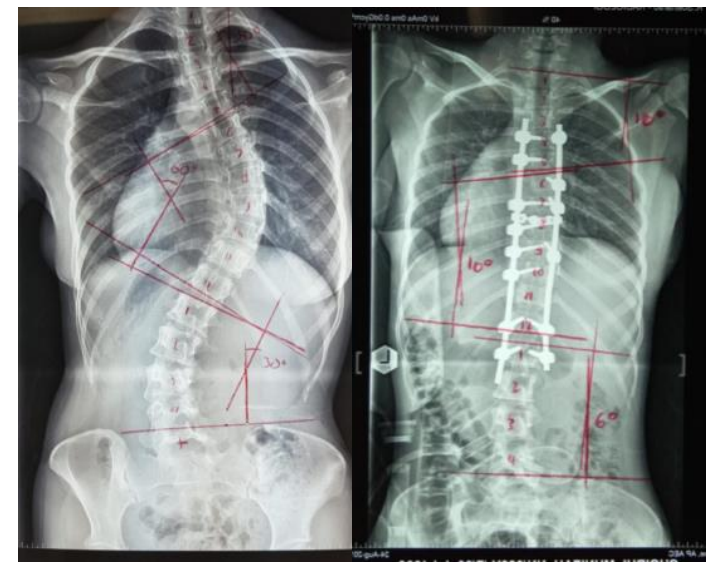

Figure 3. Female patient with adolescent idiopathic scoliosis Lenke type 1BN before (a) and after (b) selective thoracic posterior instrumented spinal fusion

In this study, the correlation test of the magnitude of main thoracic curve correction to spontaneous correction of postoperative lumbar curve and correlation test between lumbar modifier against spontaneous correction of postoperative lumbar curve and comparing the more dominant factors between 
main thoracic curve correction and lumbar modifier against spontaneous correction of lumbar curve after surgery.

Based on the correlation test with the $\mathrm{t}$ test, it was found that the large variable of main thoracic curve correction had a significant effect on the spontaneous correction of the postoperative lumbar curve, but no significant correlation was found between the lumbar modifier and spontaneous correction of the postoperative lumbar curve.

The dominant variables test that influence the use of regression coefficient values data, the magnitude of the main thoracic curve correction is the most dominant in influencing the spontaneous correction of the lumbar curve compared to the lumbar modifier.

In the literature it is explained that spontaneous correction of the lumbar curve occurs in compensation for balancing the main thoracic curve after selective thoracic fusion, the mechanism of repair of the lumbar curve that occurs is a counterbalance of correction of main thoracic curve surgery (Jansen et al., 2007).

The relationship between correction of the main thoracic and lumbar curves is also influenced by the type of the lumbar modifier, the greatest correction being obtained at the top of the lumbar curve, while the lower part of the lumbar curve is more rigid and spontaneous correction obtained is smaller (Mizusaki and Gotfryd, 2016).

Excessive main thoracic curve correction can result in decompensation of the lumbar curve, but a low degree of correction of the main thoracic curve can still leave the clinical deformity (Patel et al., 2008).

\section{REFERENCES}

Herkowitz, H.N, Garfin, S.R, Eismont, F.J, Bell, G.R, and Balderston, R.A. 2011. Rothman-Simeone The Spine 6th Edition. Philadelpia: Saunders.

Jansen, R.C., van Rhijn, L.W., Duinkerke, E., and van Ooij, A. 2007. Predictability of the spontaneous lumbar curve correction after selective thoracic fusion in idiopathic scoliosis. Eur Spine J. 16(9). pp:1335-42.

Labelle, H., Richards, S.B., De Kleuver, M., Grivas, T.B., Luk, K.D., Wong, H.K., Thometz, J., Beausejour, M., Turgeon, I., and Fong, D.Y. 2013. Screening for adolescent idiopathic scoliosis: an information statement by the scoliosis research society international task force. Scoliosis. 8(1). p: 17.

Lenke, L. G. 2007. The Lenke classification system of operative adolescent idiopathic scoliosis. Neurosurg Clin N Am. 18(2). pp: 199-206. doi: 10.1016/j.nec.2007.02.006.

Mizusaki, D. and Gotfryd, A. O. 2016. Assessment of spontaneous correction of lumbar curve after fusion of the main thoracic vertebrae in Lenke 1 adolescent idiopathic scoliosis. Revista Brasileira de Ortopedia. scielo 51. pp: 83-89. 
Patel, P.N., Upasani, V.V., Bastrom, T.P., Marcks, M.C., Pawelek, J.B., Belts, R.R., Lenke, L.G., and Newton, P.O. 2008. Spontaneous lumbar curve correction in selective thoracic fusions of idiopathic scoliosis: a comparison of anterior and posterior approaches. Spine. 33(10). pp: $1068-73$.

Solomon, L., Warwick, D. and Nayagam, S. 2017. Apley's System of Orthopaedics and Fractures. Boca Raton: CRC Press.

Studer, D., Awais, A., Williams, N., Antoniou, G., Eardley-Harris, N., and Cundy, P. 2015. Selective fusion in adolescent idiopathic scoliosis: a radiographic evaluation of risk factors for imbalance. Journal of children's orthopaedics. 